\title{
KOMPETENSI PENGAWAS DALAM SUPERVISI AKADEMIK \\ PADA SMP DI KOTA SEMARANG
}

NELFA ROZA

17002021

Email : rozanelfa78@gmail.com

\begin{abstract}
ABSTRAK
Dua hal yang harus dimiliki oleh seorang pengawas sekolah yaitu kualifikasi dan kompetensi. Tanggung jawab seorang pengawas sekolah adalah meningkatkan kualitas proses belajar mengajar dan hasil belajar siswa dalam rangka pencapaian tujuan pendidikan, terlebih pada era globalisasi saat ini tuntutan seorang pengawas sekolah menjadi lebih berat. Tujuan yang ingin dicapai dalam artikel yang saya kutip adalah mengetahui gambaran pengawas dalam supervisi akademik pada SMP di kota semarang. Hasil penelitian diperoleh beberapa temuan penilaian terhadapa kompetensi pengawas sekolah dalam supoervisi akadenmik yaitu terkait dengan (1) pembimbingan kepala sekolah pada tiap mata pelajaran dari rumpun mata pelajaran yang relevan, (2) berkenaan dengan tugasnya untuk membimbing guru dalam menyusun silabus tiap mata pelajaran berdasarkan pengembangan KTSP, (3) pembimbing dalam melaksanakan kegiatan pembelajaran/bimbingan (di kelas, laboraturium, dan atau di lapangan) untuk tiap mata pelajaran dalam rumpun mata pelajaran yang relevan. Berdasarkan bebrapa temuan tersebut perlu diacari solusinya, agar hubungan antara supervisor dan supervisee dapat berjalan dengan lancar tanpa ada hambatan, melalui penilaian multirater (berdasarkan teori 360 degree feedback). Harapannya agar pengawas sekolah mengetahui kekurangan dan adanya perbaikan di masa depan.
\end{abstract}

Kata Kunci: Pengawas, Supervisi, Semarang

\section{LATAR BELAKANG}

Berdasarkan permendiknas no. 12 tahun 2007, tentang Standar Pengawas Sekolah/Madrasah. Ada dua hal yang harus dimiliki oleh pengawas sekolah yaitu: kualifikasi dan kompetensi yang harus dimiliki tersebut adalah kompetensi kepribadian, supervisi manajerial, supervisi akademik, evaluasi pendidikan, penelitian dan pengembangan dan kompetensi sosial. Kompetensi pengawas satuan pendidikan tersebut dapat diperoleh melalui uji kompetensi dan pelatihan dari pemerintah. Tugas pengawas disini yaitu membina, mengarahkan, membimbing guru agar dapat mengelola kelas dengan profesional, medidik siswanya agar berakhlak mulia, cerdas, memiliki kreativitas dan inovasi dalam pembelajaran agar pembelajaran tersebut lebih bermakna. Karena guru adalah orang yang dijadikan teladan oleh para siswanya dan orang berhadapan langsung dengan proses belajar mengajar dikelas, guru dituntut tidak hanya mengajar tetapi juga mendidik siswa. Tuntutan guru yang profesional dan berdedikasi menjadi suatu keharusan dan kunci kesuksesan siswanya. Guru adalah pendidikan profesional yang tugas utamanya mendidik, mengajar, membimbing, mengarahkan, melatih, menilai, dan mengevaluasi peserta didik (UU No. 14 Tahun 2005 tenatang Guru dan Dosen). 
Sesuai dengan keputusan Menpan No.118 Tahun 1996 menyatakan bahwa pengawas sekolah adalah pejabat fungsional yang berkedudukan sebagai pelaksana teknis untuk melakukan kepengawasan pendidikan terhadap sejumlah sekolah yang ditetapkan. Seorang pengawas bertanggung jawab untuk meningkatkan kualitas proses belajar mengajar/bimbingan dan hasil prestasi belajar siswa dalam rangka mencapai tujuan pendidikan, terlebih di era globalisasi sekarang ini maka tanggung jawab seorang pengawas semakin berat. Tapi yang menjadi persoalan pada pengawas pada saat sekarang ini yaitu profesi sebagai pengawas hanya dijadikan sebagai masa tunggu untuk menjadi pensiun. Masih banyak pengawas yang kemampuannya belum memadai untuk menjadi seorang pengawas terlebih seorang pengawas dibebankan dengan banyak sekolah maka hal ini menyebabkan pengawas tersebut tidak tahu bagaiman proses yang terjadi dikelas, hal tersebut mengakibatkan kurangnya monitoring oleh pengawas tersbut terhadap sekolah sehingga menyebabkan lemahnya motivasi guru dalam memberikan pengajaran dengan strategi yang lebih bervariasi.

Berdasarkan uraian diatas rumusan masalah dalam tulisan ini adalah bagaimana gambaran kompetensi pengawas dalam supervisi akademik pada SMP di kota Semarang?. Tujuan tulisan ini adalah untuk mengetahui gambaran kompetensi pengawas dalam supervisi akademik pada SMP di kota Semarang.

\section{PEMBAHASAN}

\section{Penilaian Kepala Sekolah Terhadap Pengawas Sekolah tentang Supervisi}

Responden pada penelitian dalam artikel ini adalah guru, dan kepala sekolah. Total sampel adalah 41 SMP, 14 SMPA Negeri, dan 27 SMP swasta. Responden dipilih dari masingmasing sub rayon sebanyak lima sekolah. Responden menilai kompetensi kepala sekolah terkait dengan kapasitasnya sebagai supervisi akademik yang dilakukannya.(Rahayu 2014)

Hasil penelitian menunjukkan bahwa tentang kompetensi pengawas untuk melakukan pembimbingan dalam melaksanakan kegiatan pembelajaran/bimbingan (di kelas, laboraturium, dan di lapangan) untuk tiap mata pelajaran dalam rumpun mata pelajaran yang relevan kualifikasinya masih rendah. Padahal pada kegiatan ini sangat penting untuk mengarahkan dan membimbing guru dalam pembelajaran. Terlebih dalam pembelajaran IPA guru dituntut untuk mendayagunakan fungsi laboraturium sebagai bagian central kegiatan pembelajaran. Penelitian menunjukkan bahwa siswa yang dihadapi langsung dengan berbagai permasalahan dalam pembelajaran maka akan membuat siswa tersebut akan memiliki pengalaman belajar yang lebih berkesan dan lebih membangun wawasan siswa yang lebih luas.

Jika pada pengawas dan yang diawasi masih terjadi ketimpangan atau masalah diantaranya maka akan sangat menurunkan tingkat kualitas guru dalam mengajar dikelasnya, dan hal ini berdampak pada kemampuan peserta didik dalam mencapai tujuan pembelajaran. Jika hubungan antara pengawas dan yang diawasi berjalan dengan baik maka akan berpengaruh kuat terhadap kinerja yang dilakukan dari pada kemampuan. Handley (1982) menemukan korlasi yang signifikan antara supervisor pelatih dan peserta latihan dalam pengawasan. Dengan terjalinnya hubungan yang baik tersebut maka akan berdampak pula terhadap kualitas guru dalam mengajar peserta didik, hal ini juga menunjang tercapainya proses belajar yang berkualitas. 


\section{Penilaian Guru Terhadap Pengawas Sekolah Tentang Supervisi}

Hasil penelitian dari penilaian guru ini menunjukkan bahwa masih rendahnya kompetensi pengawas sekolah dalam melakukan pembimbingan pada tiap mata pelajaran pada rumpun mata pelajaran yang relevan. Jika proses pengawasan diras masih ada hambatan maka ini akan berdampak terhadap proses pembelajaran peserta didik tentunya dan akan menurunkan kualitas proses belajara siswa. Hubungan antara pengawas dengan yang diawasi sangatlah menentukan keberhasilannya proses pembelajaran. Kekurangan efektifitasnya hubungan ini akan berdampak pada kualitas pendidikan kita.

Berkenaan dengan masih adanya persoalan tetang kurangnya kompetensi pengawasan terhadap bimbingan dalam mata pelajaran dan pembimbingan di laboraturium, maka timbul adanya solusi terhadap persoalan ini yaitu perlu adanya perubahan terhadap teknik dan strategi pendekatan pengawasan. Maka dengan adanya solusi tersebut bisa lebih dapat meningkatakan kinerja dari pengawas sekolah karena penelitian membuktikan jika sebuah kinerja telah didokumentasikan maka tidak akan bisa atau sulit untuk di proses lagi nantinya. Kualitas belajar Indonesia di indikasikan belum memenuhi kualitas yang diharapkan sebagaimana dikemukakan oleh Sabandi (Ahmad 2013)

\section{KESIMPULAN DAN SARAN}

Berdasarkan uraian di atas, jadi dalam jurnal ini dipaparkan hasil-hasil penelitian yang diperoleh dari angket yang sudh disebarkan dengan dua jenis responden. Juranl yang saya kutip benar-benar membahas apa dan bagimananya kinerja pengawas sekolah tersebut dalam supervisi akademik, ternyata setelah dilakukan penelitian masih banyak terdapat pengawas tersebut menyimpang dari bagaimana hal yang semestinya. Oleh karena itu akan menyebabkan menurunnya kualitas pembelajaran peserta didik, disebabkan karena kurangnya motivasi dari guru dan kurangnya pengawasan dari pengawas sekolah. Hal ini harus diatasi oleh berbagai pihak baik pemerintah maupun dari sekolahnya sendiri agar kualitas pendidikan kita menjadi lebih baik dan maksimal misalnya dengan cara merubah atau mentranformasi strategi atau teknik pendekatan pengawasan. Sarannya dari permasalahan yang terjadi bisa dicarikan solusinya bersama-sama agar terjadinya perubahan yang lebih baik untuk masa depan nantinya.

\section{REFERENSI}

Ahmad, Sabandi. 2013. "Supervisi Pendidikan Untuk Pengembangan Profesionalitas Guru Berkelnajutan.” Pedagogi, Jurnal Ilmiah Ilmu Pendidikan XIII (2): 1-9. http://ejournal.unp.ac.id/index.php/pedagogi/article/view/4275.

Rahayu, Ayu. 2014. "Kompetensi Pengawas Dalam Supervisi Akademik Pada Smp Di Semarang." Jurnal Pendidikan Sains Universitas Muhammadiyah Semarang 02 (01): 613. 